\title{
Microbial Fuel CELl (MFC) TECHNOLOGY FOR HOUSEHOLD WASTE REDUCTION AND BIO- ENERGY PRODUCTION
}

\author{
Sanju Sreedharan ${ }^{1}$ and Renu Pawels ${ }^{2}$ \\ ${ }^{1}$ Research Scholar, Civil Engineering Division, School of Engineering, CUSAT, \\ Kochi- 682 022, Kerala, India \\ ${ }^{2}$ Head, Civil Engineering Division, School of Engineering, CUSAT, \\ Kochi- 682 022, Kerala, India
}

\begin{abstract}
MFC is a bioreactor, extracts chemical energy from organic compounds, directly as electrical energy, through microbial degradation under anaerobic conditions. The main objective of the current study is to compare the degradation ability and corresponding electric potential development from different household substrates using lab scale MFC. 50hr batch experiments were conducted with household organic rich substrates like coconut water, rice starch and milk. Different concentrations of $\mathrm{KMnO}_{4}$ were used as oxidizing agent in the cathode chamber. A voltage of about 300to $700 \mathrm{mV}$ was produced from $125 \mathrm{ml}$ of substrates seeded with cow dung. Coconut water and starch produced electric potential with the support of oxidizing agent $\mathrm{KMnO}_{4}$, where as the potential produced by milk found to be independent of the $\mathrm{KMnO}_{4}$ concentration. The maximum electric potential developed was $762 \mathrm{mV}$ from coconut water at $1500 \mathrm{mg} / \mathrm{K} \mathrm{KnO}_{4}$ with a COD reduction of $22 \%$.
\end{abstract}

\section{KEYWORDS}

Bio-Energy, Household waste organic substrates, Microbial degradation, Electric potential, Oxidizing agent

\section{INTRODUCTION}

Industrialization and growth of population have resulted in severely increased demand of fossil fuels for energy. The increase of energy cost, depletion of non-renewable energy sources like fossil fuels and intolerable changes in the climate have considerably motivated scientists to work on finding new alternative energy production approaches. The other by-product of development is wastewater, produced from different sectors [1]. Hence Green energy is the need of the day. In the field of wastewater treatment, the conventional approach is to remove the pollutants or contaminants from wastewater and discharge the effluent to any water bodies. Here the challenges are of multiphase. The partially treated effluent from wastewater treatment plants affects the quality of water reserves, the separated contaminants create disposal problems and along with that treatment plants consume huge amount of energy. Microbial Fuel Cell (MFC) Technology is an approach in which, wastewater is considered as a resource, where wastewater is cleaned for re-use and energy is produced from the contaminants with a lower carbon footprint. Biodegradable organic-rich wastes from domestic, industrial and agricultural sectors are the ideal candidates as green energy sources for electrical production, since energy is biologically extracted from them and the wastes are treated concurrently. 
MFC is a bioreactor that extracts chemical energy in the chemical bonds of organic compounds directly as electrical energy through catalytic reactions of microorganisms under anaerobic conditions. MFCs produce electricity from organic waste directly, without the need for methane collection, its conversion to heat by combustion and then to electricity. The bio-conversion in MFCs can occur at low substrate concentration levels and at temperatures below $20^{\circ} \mathrm{C}$, where anaerobic digestion generally fails due to low reaction rates and high solubility of the methane produced. Power generation of MFC depends on many factors including type of membrane, catalyst, substrate, configuration, temperature etc [2].

Typically, MFCs, as it is shown in Figure 1, consist of anode and cathode chambers, separated by a proton exchange membrane (PEM). Organic matter or biomass is oxidized under anaerobic condition at the anode producing $\mathrm{CO}_{2}$, protons as well as electrons. Microorganisms here fulfil the role of biocatalysts. The protons are diffused to the cathode chamber through the PEM or CEM (Cation Exchange Membrane).Electrons produced by the bacteria from these substrates are transferred to the electrode (anode) and flow to the cathode (positive terminal) linked by a conductive material containing a resistor or device (like LED Bulb). Oxygen has usually been a final electron acceptor in the cathode due to its convenience, strong oxidation potential, and not being a chemical waste product. The electrons that reach the cathode through external circuit combine with protons and oxygen and the resulting product is water $[3,4,10]$.

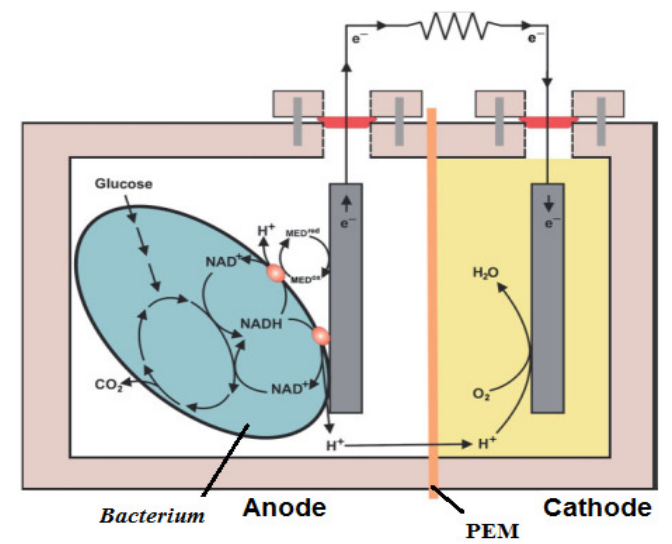

Figure 1. Schematic Sketch of Microbial Fuel Cell [5]

The bio-chemical reactions taking place in anode and cathode cells of MFC to create energy can be explained by Eq. (1).

Anode reaction $: \mathrm{C}_{6} \mathrm{H}_{12} \mathrm{O}_{6}+6 \mathrm{H}_{2} \mathrm{O} \rightarrow 6 \mathrm{CO}_{2}+24 \mathrm{H}^{+}+24 \mathrm{e}^{-}$

Cathode reaction : $24 \mathrm{H}^{+}+24 \mathrm{e}^{-}+6 \mathrm{O}_{2} \rightarrow 12 \mathrm{H}_{2} \mathrm{O}$

$$
\mathrm{C}_{6} \mathrm{H}_{12} \mathrm{O}_{6}+6 \mathrm{O}_{2} \rightarrow 6 \mathrm{CO}_{2}+6 \mathrm{H}_{2} \mathrm{O}+\text { Electrical energy }
$$

Electrical energy theoretically approaching - $2840 \mathrm{~kJ} / \mathrm{mol}$. [6]

Oxygen is having very slow reduction kinetics on graphite; therefore, it is one of the restricting agents in MFCs [7]. To alleviate this challenge, Potassium Ferri-cyanide $\left(\mathrm{K}_{3}\left[\mathrm{Fe}(\mathrm{CN})_{6}\right]\right)$ is the commonly used oxidizing agent in most of the researches $[4,8,9]$. The two chambered MFC, using artificial sucrose wastewater as the substrate and hydrogen-producing mixed bacteria as the anodic inoculums, aerated catholyte and potassium ferricyanide catholyte were operated separately to differentiate the power generation. The paper reported that the reactor with potassium ferricyanide catholyte produced higher power. The effect of potassium ferricyanide concentrations in catholyte ( $\mathrm{pH} 7.0,100 \mathrm{mM}$ phosphate buffer solution) on electricity generation 
characteristics was reported that the maximum resultant MFC output power density of 181.48 $\mathrm{mW} / \mathrm{m} 3$ was produced using a potassium ferricyanide concentration of $0.1 \mathrm{M}$ in the catholyte. [8]

In a two chambered mediator less MFC using glucose as substrate and three different electron acceptors potassium permanganate $\left(\mathrm{KMnO}_{4}\right)$, potassium ferricyanide $\left(\mathrm{K}_{3}\left[\mathrm{Fe}(\mathrm{CN})_{6}\right]\right)$ and potassium dichromate $\left(\mathrm{K}_{2} \mathrm{Cr}_{2} \mathrm{O}_{7}\right)$ were compared. The salt bridge connected MFC reported to produce a maximum potential of $1.04 \mathrm{~V}$ with $\mathrm{KMnO}_{4}$. Performance of MFC with $\mathrm{K}_{3}\left[\mathrm{Fe}(\mathrm{CN})_{6}\right]$ and $\mathrm{K}_{2} \mathrm{Cr}_{2} \mathrm{O}_{7}$ were much lower with a maximum potential of $0.71 \mathrm{~V}$ and $0.56 \mathrm{~V}$ respectively.[11] The present study was conducted on a recreated version of MFC using locally available substrates. Worldwide, several studies were reported on analyzing MFC using synthetic organic wastes. But this study was conducted with a MFC system using natural substrates like coconut water, starch drained from boiled rice and milk solution (50\% dilution) as substrates, which are available and generally thrown away from $90 \%$ of households and restaurants of Kerala. Being a poisonous chemical, Potassium Ferri-cyanide $\left(\mathrm{K}_{3}\left[\mathrm{Fe}(\mathrm{CN})_{6}\right]\right)$ was replaced with $\mathrm{KMnO}_{4}$, as the oxidizing agent in cathode chamber at different concentrations.

\section{EXPERIMENTAL INVESTIGATIONS}

\subsection{Materials}

Acrylic is a useful, clear plastic that resembles glass, but stronger than glass and resistant against chemical attack. A lab scale, two chambered MFC model was designed having a capacity of $125 \mathrm{ml}$ each. The connecting side of each chamber was provided with $30 \mathrm{~mm}$ diameter hole, where the cation exchange membrane separates the chambers. The cation exchange membrane, CMI-7000 (Membranes International Inc., NJ, USA) was used for the internal conductivity between chambers. Graphite electrodes connected with light gauge wires were used for the external circuit of MFC. The anode and cathode chambers were connected by nuts and bolts. To prevent leakage between chambers rubber gaskets with $30 \mathrm{~mm}$ hole at the centre were used and sealed with M-seal.

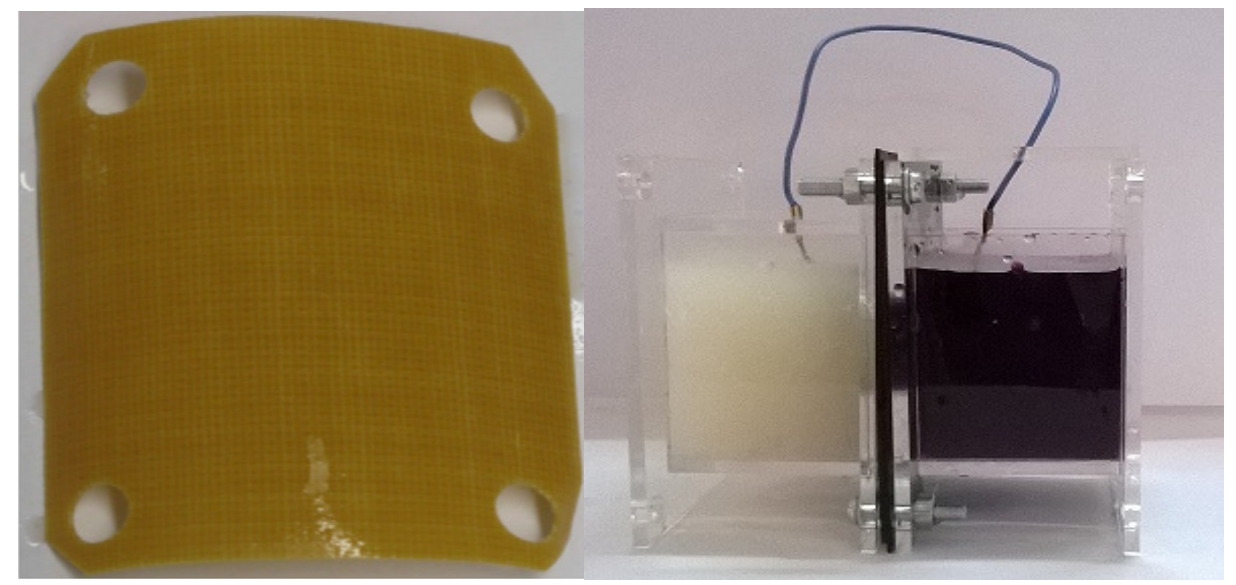

Figure2.CEM \& MFC Configuration (Photograph)

Coconut water, boiled rice drain water (starch) and milk solution were used as organic substrate in the anode chamber. Different concentrations of $\mathrm{KMnO}_{4}$ were used in the cathode chamber. A Digital Multimeter was used for the measurement of electrical potential between electrodes. Initial and then final COD of the substrate samples were evaluated to find the treatment efficiency. 


\subsection{Methodology}

Experimental evaluation was done in the microbial fuel cell (MFC) lab model as shown in Figure 2. The experimentation was done in three stages using three different substrates: Coconut water, boiled rice drain water (starch) and milk residue. In the first stage, coconut water was used as the substrate for biodegradation and hourly electric potential generation was monitored for 50 Hours as a batch reactor. Cathodic chamber was loaded with $500 \mathrm{mg} / 1,1000 \mathrm{mg} / 1,1500 \mathrm{mg} / \mathrm{l}$ and $2000 \mathrm{mg} / \mathrm{l}$ of $\mathrm{KMnO}_{4}$ and on controlled system without $\mathrm{KMnO}_{4}$. Inoculum for seeding was prepared, by adding $245 \mathrm{ml}$ of coconut water with $5 \mathrm{ml}$ cow dung, one day before setting up of the cell. While loading the MFC, $115 \mathrm{ml}$ of fresh coconut water was seeded with $10 \mathrm{ml}$ of the prepared inoculum. The experiment was carried out without any control over temperature or $\mathrm{pH}$. The same procedure was repeated using boiled rice drain water (starch) and milk solution as substrate with 50Hrs batches. Developments of Electrical potential, with respect to different concentrations of $\mathrm{KMnO}$, were evaluated. Hourly Voltage fluctuations were measured using Digital Multi-meter. The measurements were plotted to compare the effect of concentration of oxidising agentKMnO${ }_{4}$ in the cathodic chamber on Electric potential developed (in $\mathrm{mV}$ ). The values were compared with a control batch in which, the aerobic condition on cathode chamber was dependent only on natural surface aeration.

\section{RESUltS AND DisCUSSIONS}

\subsection{MFC using Coconut water as substrate}

The variation in electric potential developed between anode and cathode, using coconut water as substrate, with respect to time is represented in figure 3 . The change in concentration of $\mathrm{KMnO}_{4}$ showed significant effect in the potential developed. Optimum concentration of $\mathrm{KMnO}_{4}$ is $1500 \mathrm{mg} / \mathrm{l}$ producing a maximum potential of $762 \mathrm{mV}$ (half the potential of common battery). Potential development except in $1000 \mathrm{mg} / \mathrm{l}$, showed a similar pattern of steep increase at initial time period either ended ata steady state or decrease after a steady state, within 50hrs.

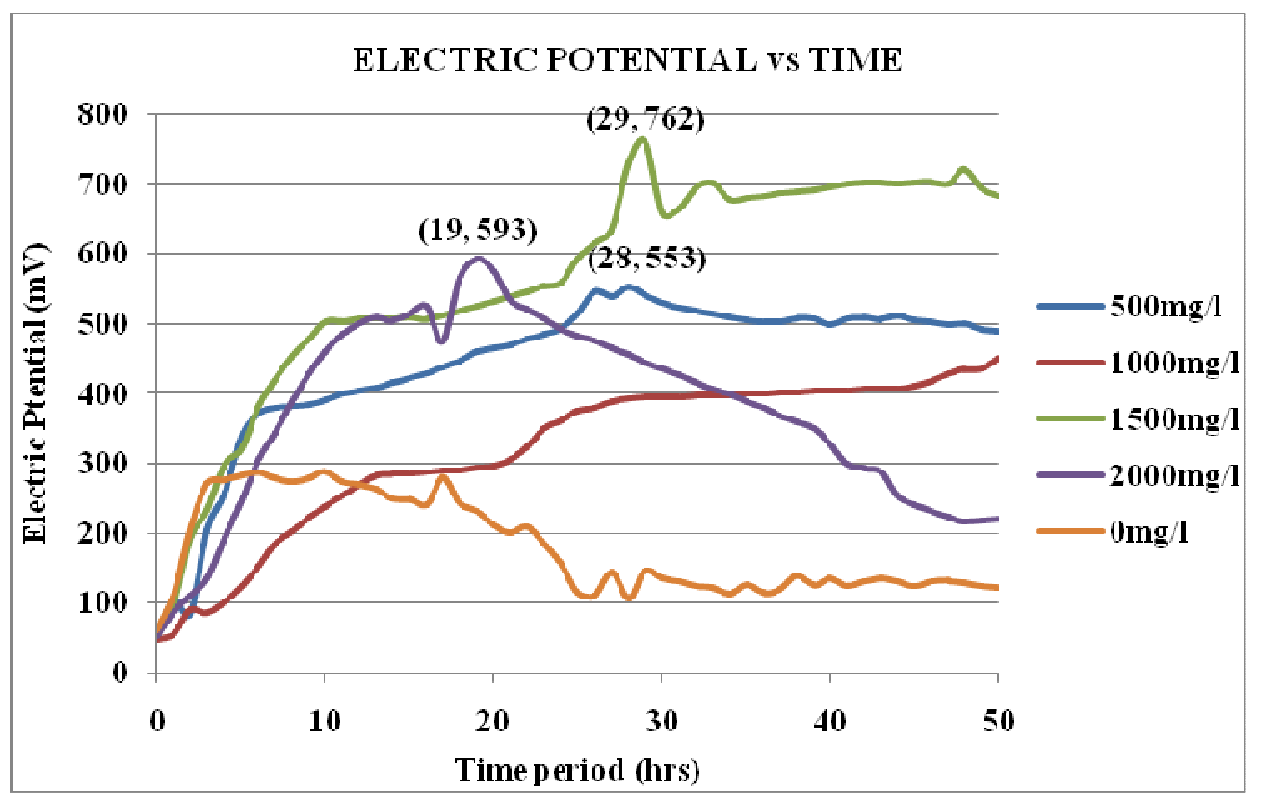

Figure 3. Hourly variation in Electric Potential developed in MFC using Coconut water as substrate and different concentrations of $\mathrm{KMnO}_{4}$ as cathode medium 
The figure 3 showed that there was significant effect on the availability of proton accepter in cathode chamber, in the development of potential. Since biodegradation rate of substrate in the anode chamber produce electrons, higher concentration of $\mathrm{KMnO}_{4}$ will not influence the development of potential.

\subsection{MFC using boiled rice drain water (starch)as substrate}

The variation in electric potential developed between anode and cathode, using boiled rice drain water (starch) as substrate, with respect to time is represented in figure 4 . The change in concentration of $\mathrm{KMnO}_{4}$ showed significant effect in the potential developed. Optimum concentration of $\mathrm{KMnO}_{4}$ was found to be $1000 \mathrm{mg} / \mathrm{l}$ producing a maximum potential of $335 \mathrm{mV}$. Potential development showed a similar pattern of steep increase at the initial time period and ended at a steady state of around $250 \mathrm{mV}$, within $50 \mathrm{hrs}$.

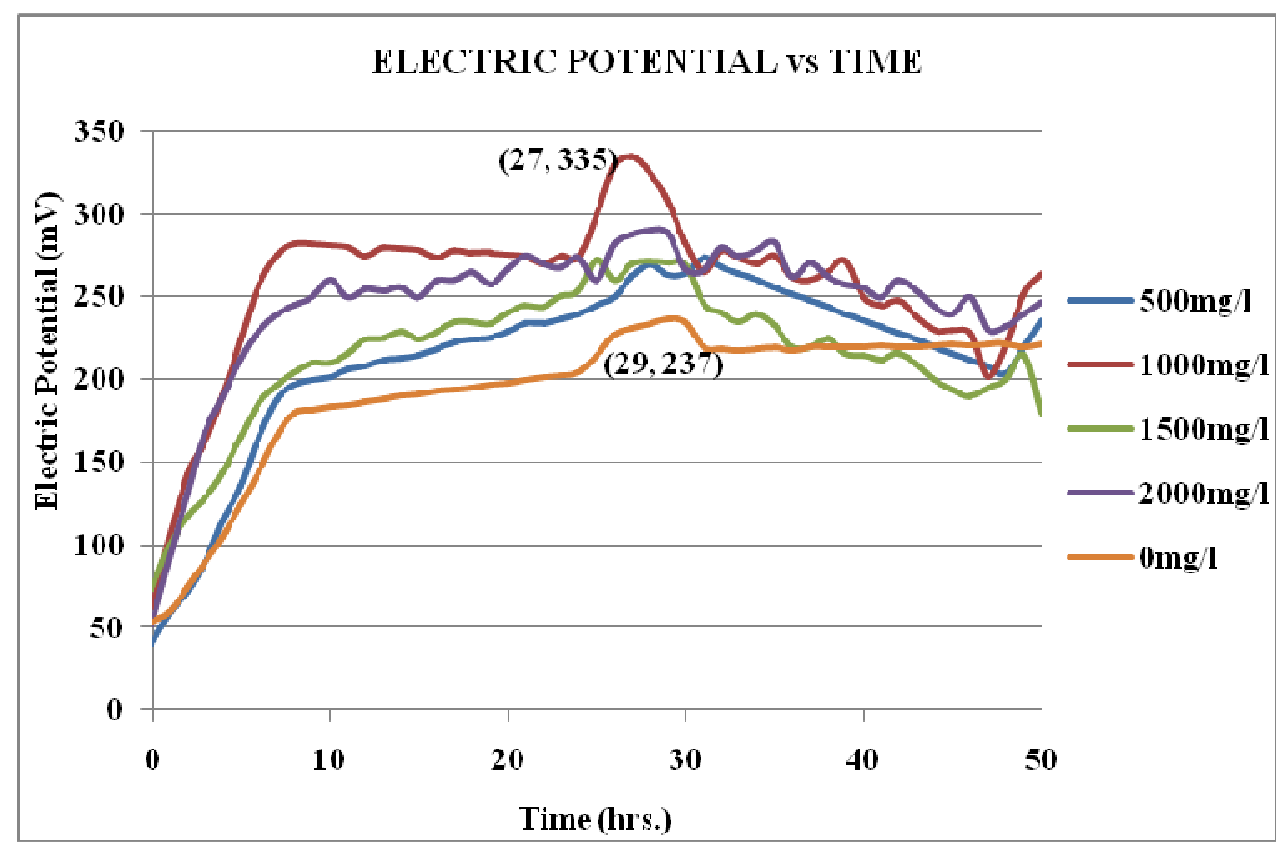

Figure 4. Hourly variation in Electric Potential developed in MFC using starch as substrate and different concentrations of $\mathrm{KMnO}_{4}$ as cathode medium

The figure 4 clearly indicated the effect on the availability of proton accepter in cathode chamber, in the development of potential. Similar to MFC using coconut water as substrate, high concentration of $\mathrm{KMnO}_{4}$ was not influenced in the development of electric potential. The lower potential development in the system compared to coconut water was due to the complexity and suspended nature of organic substances in the starch solution. But it gives a steady potential for a very long period, slow but steady biodegradation.

\subsection{MFC using milk solution as substrate}

The variation in electric potential developed, using milk solution (50\% diluted milk) as substrate, with respect to time is represented in figure 5 . At a $\mathrm{KMnO}_{4}$ concentration of $1000 \mathrm{mg} / \mathrm{l}$, a maximum potential of $389 \mathrm{mV}$ was observed. But a steady increase in Potential was achieved in the absence of $\mathrm{KMnO}_{4}$ to the maximum of $429 \mathrm{mV}$. 


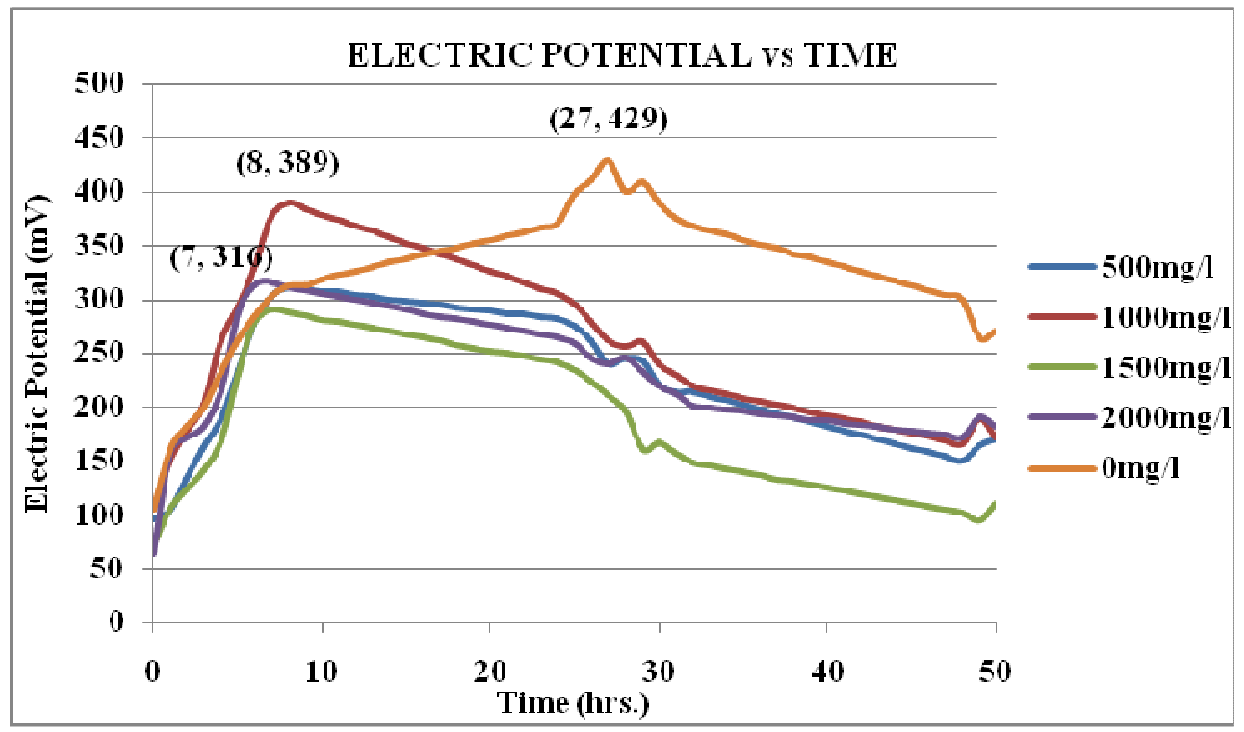

Figure 5. Hourly variation in Electric Potential developed in MFC using Milk solution as substrate and different concentrations of $\mathrm{KMnO}_{4}$ as cathode medium

MFC using milk showed a similar pattern of steep increase at initial time period followed by a steep decease in presence of $\mathrm{KMnO}_{4}$, within $50 \mathrm{hrs}$. In the absence of $\mathrm{KMnO}_{4}$, a steady but slow increase and a similar decrease was observed. The physical examination showed formation of settled floc in the anode chamber. Hence it revealed the effect of curding in the development of electric potential rather than biodegradation in presence of $\mathrm{KMnO}_{4}$. Electrons produced by biodegradation from the settling floc cannot be effectively transferred to the electrodes and hence showed a steep decrease in electric potential.

\subsection{COD removal Efficiency in MFC}

Table 1 COD reduction in MFC compared to Natural Biodegradation

\begin{tabular}{|c|c|c|c|c|}
\hline \multirow{2}{*}{ Status of sample } & \multicolumn{3}{c|}{$\%$ Reduction of COD within 50hrs of Detention } \\
\cline { 2 - 5 } & Coconut water & Starch & Milk solution \\
\hline \multirow{2}{*}{$\begin{array}{c}\text { Seeded sample kept anaerobically } \\
\text { at room temperature }\end{array}$} & $10 \%$ & $25 \%$ & $15 \%$ \\
\hline \multirow{2}{*}{$\begin{array}{c}\text { Seeded sample } \\
\text { loaded in MFC } \\
\text { at different } \\
\text { concentrations } \\
\text { of } \mathrm{KMnO} 4\end{array}$} & $0 \mathrm{mg} / 1 \mathrm{KMnO} / \mathrm{KMnO}_{4}$ & $16 \%$ & $50 \%$ & $30 \%$ \\
\cline { 2 - 5 } & $1 \mathrm{mg} / 1 \mathrm{KMnO}_{4}$ & $21 \%$ & $53 \%$ & $20 \%$ \\
\cline { 2 - 5 } & $1.5 \mathrm{mg} / \mathrm{KMnO}_{4}$ & $22 \%$ & $62 \%$ & $23 \%$ \\
\hline
\end{tabular}

Table 1 showed the COD reduction efficiencies of different substrates in MFC compared to the natural anaerobic reduction of COD of the same substrates. Initial COD of substrates were found to be $48000 \mathrm{mg} / \mathrm{l}$ for coconut water, $31000 \mathrm{mg} / \mathrm{l}$ for starch and $50000 \mathrm{mg} / \mathrm{l}$ for Milk solution. Approximately 50\% increased rate of biodegradation can be observed in MFC compared to natural anaerobic biodegradation in all substrates. This is due to the favourable condition (balance of $\mathrm{pH}$ ) for microbial growth created in MFC by the transfer of excess $\mathrm{H}^{+}$ions from anodic chamber to cathodic chamber through CEM. Starch shows the largest \% reduction of 
COD as it was the with the substrate lowest initial COD concentration. Since potential difference influence the migration rate of $\mathrm{H}^{+}$ions, slight changes are observed in the degradation efficiency of MFC with respect to concentration of $\mathrm{KMnO}_{4}$.In milk solution as substrate similar to the highest electrode potential, highest COD removal efficiency also associated with $0 \mathrm{mg} / \mathrm{l}$ of $\mathrm{KMnO}_{4}$.This result also prove that the migration efficiency of $\mathrm{H}^{+}$ions, in MFC has a significant role in the rate of biodegradation.

\section{Conclusions}

The Microbial fuel cell developed using household waste organic substrates was found to be developing higher electric potential by degradation with the support of proton accepter, $\mathrm{KMnO}_{4}$. A steady electric potential in the range of $700 \mathrm{mV}$ was developed using Coconut water as substrate with an optimised $\mathrm{KMnO}_{4}$ concentration of $1500 \mathrm{mg} / \mathrm{l}$ within $30 \mathrm{hrs}$. The lower range of steady electrical potential development $(250-300 \mathrm{mV})$ was observed in MFC using starch and milk as substrate with the support of proton accepter, $\mathrm{KMnO}_{4}$. This is due to the presence of complex organic substances in colloidal state and its slow biodegradability. The observation from this study can be concluded that:

- Increase in concentration of proton accepter / oxygen releasing substances, increase the ability to extract potential from MFC at lower concentration, but beyond some limit, the influence reduces. The optimum level of oxygen or oxidising agent depends on the substrate and its rate of biodegradation. In MFCs, the optimum concentrations of $\mathrm{KMnO}_{4}$ as proton accepter were $1500 \mathrm{mg} / \mathrm{l}$ and $1000 \mathrm{mg} / \mathrm{l}$ for substrates coconut water and starch respectively.

- When milk was used as substrate, the presence of $\mathrm{KMnO}_{4}$ as oxidising agent make curding, to reduce the potential $(250-300 \mathrm{mV})$ that is extracted from MFC. This wasdue to the change in phase of organic materials, from dissolved to suspension, which restrict biodegradability and the transfer of electrons developed during biodegradation to electrode. In the absence of $\mathrm{KMnO}_{4}$, the organic components retain in dissolved form and produced comparatively higher steady potential in the range of $350-400 \mathrm{mV}$.

- COD removal efficiency was approximately doubled irrespective of the $\mathrm{KMnO}_{4}$ concentration in anodic chamber. Hence $\mathrm{H}^{+}$ion migration in MFC from anode to cathode chamber through CEM created a favourable condition for biodegradation.

The system needs further optimization study in terms of electrode material, its structure, membrane surface area, oxidising agent used in the cathode chamber and chamber design. The electric potential of MFC can be increased by efficient seeding with specific anaerobic bacteria type suitable to substrate. Other scope is the use of mediators to improve electron conductivity from bacteria to electrode.

\section{ACKNOWLEDGEMENTS}

The authors would like to thank Aroma Plastics, Kochi for their support for casting the reactor chambers as per required design and friends for the support in purchase of Cation Exchange Membrane from Membrane International, Ringwood, USA. 
Civil Engineering and Urban Planning: An International Journal (CiVEJ) Vol.3, No.2, June 2016

\section{REFERENCES}

[1] Elnaz Halakoo, Alireza Khademi, Mostafa Ghasemi, Noordin Mohd Yusof, Rasoul Jamshidi Gohari\& Ahmad Fauzi Ismail (2015), "Production of Sustainable Energy by Carbon Nanotube/Platinum Catalyst in Microbial Fuel Cell”,Procedia CIRP, Vol. 26, pp: 473 - 476.

[2] Mostafa Ghasemi, Elnaz Halakoo, Mehdi Sedighi, Javed Alam \& Majid Sadeqzadeh (2015), "Performance comparison of three common proton exchange membranesfor sustainable bioenergy production in microbial fuel cell", Procedia CIRP, Vol. 26, pp:162 - 166.

[3] Rabaey K. \& Verstraete W. (2005), "Microbial fuel cells: novel biotechnology for energy generation”, Trends Biotechnology, Vol. 23, pp: 291-298.

[4] Mostafa Rahimnejad, Arash Adhami, Soheil Darvari, Alireza Zirepour \& Sang-Eun Oh (2015), "Microbial fuel cell as new technologyfor bioelectricity generation: A review", Alexandria Engineering Journal, Vol. 54,pp: 745-756

[5] B.E. Logan, B. Hamelers, R. Rozendal, U. Schro“ der, J. Keller, S. Freguia, P. Aelterman, W. Verstraete \& K. Rabaey (2006)“Microbial Fuel Cells: Methodology and Technology", Environmental Science Technology, Vol. 40, pp: 5181-5192.

[6] Pham T. H., Rabaey K., Aelterman P., Clauwaert P., De Schamphelaire L., Boon N. \&Verstraete, W. (2006), "Microbial Fuel Cells in Relation to Conventional Anaerobic Digestion Technology", Engineering Life Science, Vol. 6(3), pp: 285-292.

[7] G.C. Gil, I.S. Chang, B.H. Kim, M. Kim, J.K. Jang, H.S. Park \& H.J. Kim (2003), “Operational parameters affecting the performance of a mediator-less microbial fuel cell", Biosensors Bioelectronics, Vol. 18, pp: 327-334.

[8] Liling Wei, Hongliang Han \&Jianquan Shen (2012), "Effects of cathodic electron acceptors and potassium ferri cyanide concentrations on the performance of microbial fuel cell”, International Journal of Hydrogen Energy, Vol. 37, pp: 12980-12986.

[9] Zhen He and Largus T. Angenent (2006), "Review: Application of Bacterial Biocathodes in Microbial Fuel Cells", Electroanalysis, Vol.18, pp: 2009-2015.

[10] Zhuwei Du, Haoran Li, TingyueGu (2007), "A state of the art review on microbial fuel cells: a promising technology for wastewater treatment and bioenergy", Biotechnology Advances, Vol. 25, pp: 464-482

[11] N. Guerrero-Rangel, J.A. Rodriguez-de la Garza, Y. Garza-Garcia, L.J. Rios-Gonzalez, G.J. SosaSantillan, I.M. de la Garza-Rodriguez, S.Y. Martinez-Amador, M.M. Rodriguez-Garza and J. Rodriguez-Martinez (2010), "Comparative Study of Three Cathodic Electron Acceptors on the Performance of Medatiorless Microbial Fuel Cell", International Journal of Electrical and Power Engineering, Vol.4, pp:27-31

\section{Authors}

Sanju Sreedharan, is currently working as Faculty, in Civil Engineering Department of SCMS School of Engineering and Technology, Karukutty, Kerala since 2005. For the last 3 years, she is also associated with SCMS Water Institute - a research and consultancy centre on water. She had completed, B Tech Degree in Civil Engineering and M Tech Degree in Environmental Engineering from Govt. Engineering College, Thrissur and currently pursuing PhD Degree in CivilEnvironmental Engineering at School of Engineering, CUSAT, Kochi.

Dr.Renu Pawels, is currently working as Head, Civil Engineering Division of School of Engineering, CUSAT, Kochi. She has around fifteen years of research and teaching experience. She had completed, B Tech Degree in Civil Engineering from $M$ G University, $M$ Tech Degree in Environmental Engineering from Nagpur University and PhD Degree in Civil- Environmental Engineering from School of Engineering, CUSAT, Kochi.
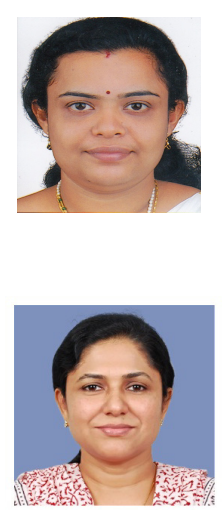